\title{
Responsivitas Pemerintah Dalam Penyelenggaraan Pendidikan Inklusif Dalam Perspektif New Public Service
}

\author{
Apdita Suci Nurani ${ }^{1 *}$, Soesilo Zauhar, Prof,Dr, MS², Choirul Saleh, Dr, M.Si ${ }^{3}$ \\ Jurusan Ilmu Administrasi, Fakultas IImu Administrasi, Universitas Brawijaya
}

\begin{abstract}
Abstrak
Responsivitas adalah bentuk kepekaan dan kemampuan dari pemerintah dalam menyelenggarakan pelayanan. Termasuk dalam pemberian pelayanan pendidikan bagi anak berkebutuhan khusus. Bentuk pelayanan tersebut adalah penyelenggaraan pendidikan inklusif. Penelitian ini memberikan gambaran mengenai kepekaan dan kemampuan pemerintah dalam penyelenggaraan pendidikan inklusif dalam persepektif new public service, dengan pendekatan kualitatif dan analisis Straus dan Corbin. Kepekaan pemerintah dilihat melalui lima prinsip: (1) akses, hal ini diwujudkan dengan adanya sekolah yang menyelenggarakan pendidikan inklusif. (2) pilihan, Kepekaan pemerintah Kota Surakarta telah dibuktikan dengan memberikan pilihan-pilihan kepada ABK dalam bidang pendidikan. (3) informasi, Kurangnya komitmen dari komponen sekolah terhadap pendidikan inklusif mengakibatkan tidak semua sekolah terang-terangan menyatakan mereka sekolah penyelenggara pendidikan inklusif. (4) perbaikan, perbaikan selalu dilakukan dengan memberikan form evaluasi untuk tiap sekolah penyelenggara pendidikan inklusif. (5) keterwakilan, terlihat dengan adanya wawancara kepada orang tua siswa ketika akan masuk ke sekolah umum. Kepekaan perlu dihubungkan dengan perspektif new public service, agar menghasilkan pelayanan yang maksimal. Sedangkan kemampuan dilihat melalui keberhasilan pemerintah dalam membuat regulasi mengenai penyelenggaraan pendidikan inklusif. Responsivitas pemerintah dalam penyelenggaraan pendidikan inklusif telah dibuktikan dengan adanya pearaturan daerah tentang perlindungan anak dan keputusan kepala dinas tentang penetapan sekolah penyelenggara pendidikan inklusif.
\end{abstract}

Kata Kunci: Responsivitas, Pemerintah dan Pendidikan Inklusif

\section{Abstract}

Responsiveness is a sensitivity and capability from the side of government to deliver governmental service, including the delivery of education service for children with specific necessities. This form of service is the implementation of inclusive education. This research illustrates about the sensitivity and capability government for the implementation of inclusive education based on New Public Service perspective. Qualitative and analytical approaches of Strauss and Corbin are used. Governmental sensitivity is counted from five principles such as (1) access, children with specific necessities are given wider access to any schools with inclusive education. (2) choice, The sensitivity of the government of Surakarta City has been proved by giving choices to ABK in selecting education . (3) information, not all school components have the expected commitment to inclusive education, and therefore, not all schools have taken account seriously the importance of inclusive education. (4) redress, redressing measures by giving evaluation form to each inclusive education provider schools. (5) representation, representation is also considered by interviewing parents when they take their children to enroll into public schools. Sensitivity must correspond with New Public Service perspective to produce maximum service. The capability is acknowledged through governmental success in making the regulation about the implementation of inclusive education. Governmental responsiveness to the implementation of inclusive education has been recognized with the presence of local regulations about children protection and also the decree of related official about the establishment of inclusive education provider schools.

Keywords: Responsiveness, Government and Inclusive Education

\section{PENDAHULUAN}

Perubahan istilah administrasi negara menjadi administrasi publik, juga ikut merubah orientasi. Orientasi administrasi negara dalam

Alamat Korespondensi Penulis:

Apdita Suci Nurani

Email : apdita_suci@yahoo.co.id

Alamat : J. Mayjen Haryono No. 163 Malang 65145 prakteknya cenderung kepada negara sebagai sesuatu yang harus diikuti, ditakuti dan dilayani. Sedangkan, orientasi administrasi publik adalah memberikan pelayanan kepada publik. Pengertian administrasi publik yang telah dikutip oleh Sjamsuddin (2006:115), menjelaskan bahwa pengertian administrasi publik dapat dibagi menjadi lima point. Pertama adalah administrasi publik merupakan suatu kerjasama kelompok dalam lingkungan pemerintahan. Ke dua, 
administrasi publik meliputi tiga cabang pemerintahan yang saling berhubungan, yaitu eksekutif, legislatif dan yudikatif. Ke tiga, administrasi publik memiliki peranan yang sangat penting dalam proses formulasi kebijakan pemerintahan, oleh karena itu merupakan bagian dari sebuah proses politik. Ke empat, administrasi publik memiliki kaitan yang erat dengan berbagai macam kelompok swasta dan perorangan dalam menyajikan pelayanan kepada masyarakat. Ke lima, dalam beberapa hal administrasi publik berbeda pada penempatan pengertian dengan administrasi perorangan[10]. Administrasi publik mengajarkan bahwa pemerintahan pada hakikatnya menyelenggarakan dua jenis fungsi utama. Menurut Hardiyansyah (2011:10) dua fungsi utama dari pemerintah yaitu menyelenggarakan fungsi pengaturan dan fungsi pelayanan[4]. Fungsi pelayanan menyangkut semua segi kehidupan dan penghidupan bermasyarakat, berbangsa dan bernegara, dan pelaksanaanya dipercayakan kepada aparatur pemerintah tertentu yang secara fungsional bertanggungjawab atas bidang-bidang tertentu kedua fungsi tersebut.

Pemerintah memiliki tanggungjawab memberikan pelayanan kepada orang dewasa maupun kepada anak. Pentingnya pelayanan kepada anak karena anak adalah generasi penerus bangsa. Sehingga anak harus harus diupayakakan menjadi kader-kader berkualitas sejak dini. Menurut Astuti (2003:6) anak adalah mereka yang masih muda usia dan sedang menetukan identitas, sehingga berakibat mudah kena pengaruh lingkungan sekitar[1]. Perlu adanya perlindungan untuk anak, agar anak bisa tumbuh dan berkembang sesuai cita-cita yang mereka harapkan. Undang-Undang Republik Indonesia Nomor 23 Tahun 2002 tentang Perlindungan Anak, menjelaskan pada dasarnya anak harus dilindungi karena anak mempunyai tingkat ketergantungan yang sangat tinggi terhadap seluruh penyelenggara perlindungan anak[15].

Perlindungan kepada anak juga diberikan kepada anak berkebutuhan khusus. Perlindungan ini biasa disebut dengan perlindungan khusus. Perlindungan khsusus perlu diselenggarakan karena masih banyak anak di Indonesia yang memiliki kebutuhan khusus. Perlindungan khusus adalah perlindungan yang diberikan kepada anak korban kekerasan, eksploitasi, penelantaran dan perlakuan salah. Perda Kota Surakarta No 4 Th 2012 tentang Perlindungan Anak, menjelaskan perlindungan khusus ini diberikan kepada beberapa tipe anak salah satunya adalah anak difabel, yaitu anak yang memiliki fisik yang berbeda dengan yang lain atau memiliki kebutuhan khusus[9].

Perlindungan kepada anak baik anak normal maupun anak yang memiliki kebutuhan khusus salah satunya adalah perlindungan dalam bidang pendidikan. Mendapatkan pendidikan yang layak merupakan hak bagi semua anak. Hal ini berdasarkan bahwa setiap anak boleh menjadi orang sukses, sesuai kemampuan dan bakat masing-masing. Pemerintah adalah pelayanan masyarakat. Pasolong (2008:128) mendefinisikan pelayanan sebagai aktivitas seseorang, kelompok dan/atau organisasi baik langsung maupun tidak langsung untuk memenuhi kebutuhan[8]. Dalam hal ini pemerintah wajib memenuhi kebutuhan dengan memberikan pendidikan yang sesuai dengan keinginan dan kebutuhan masing-masing anak. Hal ini telah dibuktikan oleh pemerintah dengan memberikan akses pendidikan dari TK, SD/MI, SMP/MTs, SMA/MA dan SMK atau biasa disebut dengan sekolah reguler. Akses ini sangat terbuka untuk anak normal, tapi dianggap cukup sulit untuk anak berkebutuhan khusus.

Anak berkebutuhan khusus telah diberikan akses di sekolah luar biasa. Akan tetapi tidak semua anak berkebutuhan khusus ingin masuk sekolah luar biasa, tidak sedikit dari mereka yang mampu dan berkeinginan masuk ke sekolah reguler. Sehingga perlu adanya program khusus yang mampu memberikan kemudahan bagi anak berkebutuhan khusus untuk masuk ke sekolah reguler. Sebelum resmi menjadi kota inklusi pada tanggal 23 september 2013, Kota Surakarta sudah memiliki 13 sekolah inklusi. Akan tetapi penyebaran sekolah inklusi belum merata di setiap kecamatan di Kota Surakarta. Penyelenggaraan harus selalu diperhatikan, agar tujuan dari pendidikan inklusif tersebut sampai kepada sasaran yaitu memenuhi kebutuhan masyarakat. $\mathrm{Hal}$ ini sesuai dengan penelitian yang dilakukan Trimo (2012), yang berjudul Manajemen Sekolah Penyelenggara Pendidikan Inklusif: Kajian Aplikatif Pentingnya Menghargai Keberagaman Bagi AnakAnak Berkebutuhan Khusus. Dalam penelitian ini dijelaskan untuk memberikan layanan bagi anakanak berkebutuhan khusus, kegiatan pembelajaran dalam kelas-kelas inklusi harus tercipta suasana belajar yang kooperatif antara siswa-siswa biasa dengan siswa yang berkebutuhan khusus. Anakanak biasa harus dikondisikan untuk memiliki sikap empati terhadap anak yang membutuhkan pendidikan khusus, dengan demikian anak yang membutuhkan pendidikan khusus akan merasa nyaman belajar bersama-sama dengan anak-anak sebaya lainnya, yang akhirnya tidak merasa inferior (rendah diri). Perlu adanya tanggung jawab dari 
pemerintah untuk mewujudkan tujuan dari pendidikan inklusif[14].

Widodo (2001:152), mengungkapkan bahwa, pemerintah dapat dikatakan bertanggung jawab jika mereka dinilai mempunyai responsivitas (daya tanggap) yang tinggi terhadap apa yang menjadi permasalahan, kebutuhan, keluhan dan aspirasi masyarakat yang diwakilinya, mereka cepat memahami apa yang menjadi tuntutan publik dan berusaha semaksimal mungkin memenuhinya, ia dapat menangkap masalah yang dihadapi publik dan berusaha untuk mencari solusinya, mereka tidak suka menunda-nunda waktu, memperpanjang jalur pelayanan, atau mengutamakan prosedur tetapi mengabaikan substansi[16]. Dengan demikian, pemerintah harus memiliki responsivitas mengenai kebutuhan dan masalah yang timbul dalam masyarakat. Responsivitas ditunjukan dengan kepekaan dan kemampuan pemerintah dalam menghadapi masalah yang timbul. Termasuk dalam bidang pendidikan untuk anak berkebutuhan khusus.

Berdasarkan hal tersebut maka dalam penelitian ini dilakukan perumusan masalah yaitu Bagaimana kepekaan dan kemampuan pemerintah menghadapi masalah yang timbul dalam penyelenggaraan pendidikan inklusif dalam perspektif new public service? Tujuan penelitian ini untuk memberikan gambaran tentang kepekaan dan kemampuan pemerintah menghadapi masalah yang timbul dalam penyelenggaraan pendidikan inklusif dalam perspektif new public service.

\section{METODE PENELITIAN}

Penelitian ini merupakan penelitian deskriptif dengan menggunakan pendekatan kualitatif. Dengan pendekatan ini peneliti memiliki kedalaman dan ketajaman dalam menganalisis untuk mengungkap fakta mengenai responsivitas pemerintah yaitu berupa kepekaan dan kemampuan dalam penyelenggaraan pendidikan inklusif dengan persepektif new public service.

\section{Metode Pengumpulan Data}

Penelitian ini menggunakan tiga sumber data yaitu pengamatan, wawancara dan dokumentasi. Metode pengamatan (Observation) dilakukan dengan melihat secara langsung kepekaan pemerintah dalam penyelenggaraan pendidikan inklusif. Metode wawancara dilakukan dengan melakukan tanya jawab dengan pejabat dan juga staff baik dari Dinas Pendidikan Pemudan dan Olahraga Kota Surakarta, maupun sekolah penyelenggara pendidikan inklusif yang berada di Kota Surakarta. Metode dokumentasi digunakan dengan melihat dokumen antara lain: Peraturan Daerah Kota Surakarta No. 4 Tahun 2012 Tentang Perlindungan Anak dan Surat Keputusan Kepala
Dinas Pendidikan Pemuda dan Olahraga Kota Surakarta Nomor 954/55/kep/sd-AUD/2013 tentang penetapan sekolah penyelenggaraan pendidikan inklusif Kota Surakarta.

Dalam penelitian ini penulis berusaha untuk menganalisis data-data yang telah dikumpulkan dengan menggunakan langkah yang tepat, sesuai dengan metode penelitian yang dilakukan. Langkah-langkah yang digunakan dalam penelitian ini menggunakan analisis data yang dikembangkan oleh Strauss dan Corbin (2003). Strauss dan Corbin menjelaskan ada tiga langkah besar dalam melakukan analisis data kualitatif, yaitu: Open Coding, Axial Coding dan Selective Coding.

\section{HASIL DAN PEMBAHASAN}

Responsivitas merupakan salah satu kriteria dalam mengukur kinerja organisasi pelayanan publik. Menurut Dwiyanto (2006:51) responsivitas secara langsung menggambarkan kemampuan organisasi publik dalam menjalankan misi dan tujuanya, terutama untuk memenuhi kebutuhan masyarakat[3]. Responsivitas memiliki persamaan arti dengan daya tanggap. Hal ini sesuai dengan konsep responsivitas menurut Blanchard yang dikutip oleh Supriyono (Jurnal Administrasi Negara, 2001:20) mengemukakan bahwa responsivitas atau daya tanggap adalah istilah popular digunakan dalam lingkup organisasi bisnis, dan dapat diartikan sebagai kemampuan untuk membantu pelanggan dalam memberikan jasa pelayanan dengan cepat[12]. Responsivitas juga harus dimiliki oleh pemerintah dalam melakukan pelayanan kepada masyarakat. Indikator responsivitas dalam pelayanan menurut Maruti (2013) yaitu, (1) terdapat tidaknya keluhan dari pengguna jasa; (2) sikap aparat birokrat dalam merespon keluhan dari pengguna jasa; (3) penggunaan keluhan dari pengguna jasa sebagai referensi bagi perbaikan penyelenggaraan pelayanan di masa mendatang; (4) berbagai tindakan aparat birokrat untuk memberikan kepuasan pelayanan kepada pengguna jasa; (5) penempatan pengguna jasa oleh aparat birokrasi dalam sistem pelayanan yang berlaku[7]. Dengan demikian responsivitas dapat diartikan sebagai daya tanggap pemerintah yang ditunjukan melalui kepekaan dan kemampuan dalam menghadapi keluhan dan kebutuhan masyarakat sebagai penerima pelayanan.

\section{Kepekaan Pemerintah Dalam Penyelenggaraan Pendidikan Inklusif}

Konsep administrasi publik adalah memberikan pelayanan kepada masyarat. Hal ini juga berlaku di Kota Surakarta. Mahmudi (2007: 213) menjelaskan pelayanan publik adalah segala kegiatan pelayanan yang dilaksanakan oleh penyelenggara pelayanan 
publik sebagai upaya pemenuhan kebutuhan publik dan pelaksanaan ketentuan peraturan perundang-undangan[6]. Kepekaan ditunjukan dengan lima prinsip, yaitu akses, pilihan, informasi, keterwakilan dan perbaikan. Hal ini kemudian di analisis menggunakan perspektif new public service agar menghasilkan pelayanan yang maksimal sesuai dengan kebutuhan masyarakat. Denhart and Denhart (2013) menjelaskan tujuh prinsip new public service yaitu Serve citizens, not customers (melayani warga negara, bukan pelanggan), Seek the public interest (mengutamakan kepentingan publik), Value citizenship over entrepreneurship (kewarganegaraan lebih berharga daripada kewirausahaan), Think strategically act democratically (berpikir strategis, bertindak demokratis), Recognize that accountability is not simple (tahu kalau akuntabilitas bukan hal sederhana), Serve rather than steer (melayani ketimbang mengarahkan), Value people, not just productivity (menghargai manusia, bukan sekedar produktivitas)[2]. Perspektif new public service adalah perbaikan dari perpektif sebelumnya yang dianggap kurang sesuai dengan tujuan pelayanan. Perspektif old public administration dianggap memiliki kelemahan sehingga menimbulkan kritik. Setelah itu muncul perspektif new public management yang dianggap juga memiliki kelemahan karena pemerintahan tidak seharusnya dijalankan seperti sebuah perusahaan, tetapi member pelayanan kepada masyarakat secara demokratis. Pernyataan Denhart \& Denhart juga dipertegas oleh Islamy (2007:18) yaitu, 1) nilai-nilai demokrasi, kewarganegaraan dan kepentingan publik adalah merupakan landasan utama/pokok dalam proses penyelenggaraan pemerintah; 2) nilai-nilai tersebut diugemi dan memberi energi kepada pegawai pemerintah/pelayanan publik dalam memberikan pelayananya kepada publik secara adil, merata, jujur dan bertanggung jawab[5].

Perspektif sebelumnya yang dianggap memiliki kelemahan, sehingga muncul perspektif baru yaitu new public service. Sesuai dengan prinsip dari new public service bahwa kepentingan publik lebih baik dijalankan oleh abdi masyarakat dan warga negara yang memiliki komitmen untuk memberikan sumbangsih bagi masyarakat daripada dijalankan oleh para manajer wirausaha yang bertindak seolah-olah uang milik sendiri. Tujuan dari program itu tetap melayani masyarakat, agar masyarakat memiliki akses, pilihan, informasi, perbaikan dan keterwakilan. Hal tersebut merupakan bentuk kepekaan pemerintah kepada masyarakat.
1) Akses

Akses yang diberikan oleh pemerintah berupa pembentukan sekolah inklusi. Sekolah inklusi adalah suatu sistem yang menyelenggarakan pendidikan yang memberikan kesempatan kepada semua peserta didik yang memiliki kelainan dan memiliki potensi dan kecerdasan dan/atau bakat istimewa untuk mengikuti pendidikan dalam satu lingkungan secara bersama-sama dengan peserta didik pada umumnya. Tujuan yang ingin dicapai dalam penyelenggaraan pendidikan inklusif adalah pemerataan pendidikan bagi anak normal maupun anak berkebutuhan khusus. Akan tetapi penyelenggaraan pendidikan inklusif tidak hanya memasukan siswa yang memiliki kebutuhan khusus ke dalam kelas reguler untuk belajar bersama-sama dengan siswa normal lainya. Lebih dari itu, bahwa sekolah inklusi adalah sistem pendidikan yang mengembangkan siswa yang memiliki kebutuhan khusus untuk dapat lebih berkembang dengan baik dalam hal akademik maupun non akademik.

Pemerintah juga memberikan akses kemudahan agar anak berkebutuhan khusus mampu beradaptasi baik dalam lingkungan maupun dalam pelajaran. Sehingga diadakan modifikasi kurikulum. Modifikasi kurikukulum yaitu menyesuaikan kurikulum yang ada dengan kemampuan siswa berkebutuhan khusus. Modifikasi kurikulum terdiri dari modifikasi tujuan yaitu tujuan pembelajaran yang ada dalam kurikulum umum dirubah untuk disesuaikan dengan kondisi siswa berkebutuhan khusus. Modifikasi isi yaitu materi pelajaran untuk siswa regular dirubah dan disesuaikan dengan kondisi siswa berkebutuhan khusus. Modifikasi proses, yaitu perbedaan dalam kegiatan pembelajaran yang dijalani oleh siswa berkebutuhan khusus dengan siswa pada umumnya. Terakhir modifikasi evaluasi yaitu perubahan dalam sistem penilaian untuk disesuaikan dengan kondisi siswa berkebutuhan khusus. Modifikasi kurikulum tidak selalu diterapkan untuk semua anak berkebutuhan khusus, tapi hanya sebagian anak berkebutuhan khusus saja yang dianggap memerlukan modifikasi kurikulum. Selain adanya modifikasi kurikulum, akses yang diberikan juga berupa adanya kelas tambahan. Kelas tambahan ini berguna untuk anak berkebutuhan khusus yang mengalami kesusahan mengikuti pelajaran yang diberikan didalam kelas. Kelas tambahan dilaksanakan diluar jam pelajaran. $\mathrm{Hal}$ ini sesuai dengan prinsip new public service yaitu penting sekali bagi abdi masyarakat untuk menggunakan kepemimpinan yang berbasis pada nilai bersama dalam membantu warna negara mengemukakan kepentingan bersama dan 
memenuhinya daripada mengontrol atau mengarahkan masyarakat kearah nilai baru.

\section{2) Pilihan}

Salah satu cara menunjukan kepekaan pemerintah kepada masyarakat adalah dengan cara memberikan beberapa pilihan pelayanan. Pilihan yang diberikan oleh pemerintah untuk anak berkebutuhan khusus dalam bidang pendidikan yaitu berbentuk adanya sekolah inklusi yang tersebar di setiap kecamatan di Kota Surakarta. Selain penyebaran sekolah-sekolah inklusi, pemerintah tetap mempertahankan sekolah luar biasa.

Tabel Penyebaran Sekolah Inklusi di Kota Surakarta Tahun 2014

\begin{tabular}{|l|l|}
\hline \multicolumn{1}{|c|}{ Kecamatan } & \multicolumn{1}{|c|}{ Sekolah Inklusi } \\
\hline Laweyan & SD N Pajang 1 \\
& SD N Karangasem 1 \\
& SD Al Islam 1 \\
& SMP N 12 \\
\hline Serengan & SD Nkartodipuran \\
& SD Al Islam 2 \\
& SMP N 22 \\
& SMP Al Islam 1 \\
\hline Pasar Kliwon & SD N Wiropaten \\
& SD N Harjodipuran \\
& SMP Islam Diponegoro \\
& SMP Kanisius 1 \\
\hline Jebres & SD N Petoran \\
& SD N Mojosongo 1 \\
& SMP N 20 \\
& SMA N 8 \\
& SMK N 8 \\
\hline Banjarsari & SD N Manahan \\
& SD N Bromantakan \\
& SD Al Firdaus \\
SD N Gebang & SD Lazuardi Kamila \\
& SMP N 23 \\
SMK N 9 \\
SMA N 5 \\
SMA Muhammadiyah 6 \\
SMK N4 \\
\hline
\end{tabular}

Sumber: Diolah dari hasil penelitian

di Dinas Pendidikan Pemuda dan Olahraga Kota Surakarta

Hal ini sesuai dengan salah satu prinsip new public service yaitu Serve citizens, not customers. Bahwa kepentingan publik merupakan hasil dialog tentang nilai-nilai bersama daripada agresi kepentingan pribadi perorangan maka abdi masyarakat tidak semata-mata merespon tuntutan pelanggan tetapi justru memusatkan perhatian untuk membangun kepercayaan dan kolaborasi dengan dan diantara warga negara. Banyaknya pilihan menunjukan pemerintah telah bersikap adil kepada masyarakat bukan kepada pelanggan yang membutuhkan. Keadilan ini ditunjukan dengan penyelenggaraan sekolah inklusi. Sekolah inklusi tidak hanya memberikan manfaat untuk anak berkebutuhan khusus, akan tetapi juga bermanfaat untuk anak normal. Sekolah inklusi mengajarkan rasa empati anak normal kepada anak berkebutuhan khusus. Sekolah inklusi juga mengajarkan rasa bersyukur dan tolong menolong kepada mereka yang memiliki kekurangan. Sehingga pemerintah mengadakan sekolah inklusi di setiap kecamatan.

\section{3) Informasi}

Informasi diberikan bertujuan untuk menimbulkan rasa tanggung jawab bersama dalam penyelenggaraan pendidikan inklusif. Sesuai dengan prinsip new public service yaitu seek the public interest. Administrator publik harus memberikan sumbangsih untuk membangun kepentingan publik bersama. Tujuanya tidak untuk menemukan solusi cepat yang diarahkan oleh pilihan-pilihan perorangan tetapi menciptakan kepentingan bersama dan tanggung jawab bersama. Sedangkan informasi diberikan kepada masyarakat melalui baliho-baliho serta kegiatan pencanangan pengembangan pendidikan inklusif di Kota Surakarta.

Penyelenggara pendidikan inklusif dalam hal ini sekolah inklusi juga telah diberikan informasi mengenai sistem pendidikan inklusif. Informasi tidak hanya diberikan kepada guru-guru, tapi juga karyawan sekolah. Informasi bertujuan agar guru dan karyawan mengetahui mengenai sekolah inklusi. Informasi dapat diberitahukan secara langsung oleh dinas terkait melalui koordinator inklusi. Koordinator inklusi adalah seorang guru yang ditunjuk menjadi tanggungjawab dalam penyelenggaraan pendidikan inklusif. Selain itu informasi juga berupa pelatihan-pelatihan atau juga study banding ke sekolah sumber. Kota Surakarta memiliki sekolah sumber salah satu nya adalah SD Al Firdaus. Sekolah sumber adalah sekolah yang dijadikan narasumber mengenai pendidikan inklusif. Penunjukan sekolah sumber didasarkan pada pengalaman dan kemampuan sekolah tersebut dalam menyelenggarakan pendidikan inklusif.

\section{Perbaikan}

Pelayanan yang baik adalah pelayanan yang selalu mengalami perbaikan. Perbaikan dikembangkan sesuai dengan kebutuhan dan untuk memenuhi tuntutan dari masyarakat yang selalu berkembang. Perbaikan telah dilakukan oleh pemerintah baik kondisional maupun isidental. Perbaikan kondisional diadakan setiap tahun dengan melakukan evaluasi. Evaluasi ini dilakukan dengan pemberian form isian evaluasi diri sekolah inklusi. Form yang diberikan untuk mengevaluasi 
jalanya penyelenggaraan pendidikan inklusif di setiap sekolah di Kota Surakarta. Form tersebut terbagi menjadi 3 bagian, yaitu: form 1 mengenai data umum sekolah, form 2 mengenai data khusus sekolah dan form 3 mengenai implementasi sekolah inklusi. Masing-masing form memiliki pertanyaan dengan jawaban tertutup. Setiap jawaban memiliki sekor dari nol sampai tiga, sesuai dengan jawaban yang diberikan. Setelah mengetahui sekor masing-masing form, kemudian sekor tersebut dijumlah menjadi satu. Sekor tersebut menentukan posisi sekolah saat ini dalam penyelenggaraan pendidikan inklusif. Setelah diketahui posisi sekolah saat ini, maka akan diketahui kategori tiap sekolah penyelenggara pendidikan inklusi. Kategori tersebut terbagi menjadi lima, yaitu kategori sangat kurang, kurang, cukup/sedang, baik dan sangat baik.

Evaluasi ini bertujuan untuk mengetahui ketegori yang diperoleh tiap-tiap sekolah. Dengan mengetahui kategori tersebut, sekolah maupun dinas yang bertanggung jawab mengetahui kekurangan dan segera melalukan perbaikan. Perbaikan harus selalu dilakukan untuk memenuhi tuntutan pelanggan yang selalu berkembang. Hal ini menunjukan bahwa keberhasilan dapat dicapai dalam jangka panjang jika dijalankan melalui proses kolaborasi dan kepemimpinan bersama dan didasarkan pada penghargaan kepada semua orang. Sesuai dengan prinsip new public service, yaitu value people, not just productivity. Karena untuk mencapai sekolah inklusi perlu proses dan perbaikan yang selalu dilakukan.

Perbaikan juga dilakukan secara isidental. Perbaikan secara isidental dilakukan jika merasa dibutuhkan saja. Perbaikan isidental salah satunya perbaikan yang dilakukan pihak sekolah dengan mengadakan studi banding di sekolah sumber. Salah satu sekolah sumber yang biasa digunakan untuk studi banding penyelenggaraan pendidikan inklusif adalah SD Al Firdaus. Studi banding tidak hanya mengetahui mengenai memperlakukan anak berkebutuhan khusus didalam kelas, akan tetapi studi banding juga mempelajari mengenai penyelenggaraan proses belajar mengajar serta administrasi sekolah inklusi. Proses belajar mengajar serta administrasi akan sedikit berbeda antara sekolah pada umumnya dengan sekolah inklusi. Karena di sekolah inklusi aka nada program-program baru yang diperuntukan untuk anak berkebutuhan khusus.

\section{Keterwakilan}

Keterwakilan masyarakat dalam menentukan sebuah kebijakan merupakan hal yang sangat penting. Hal ini dikarenakan masyarakat adalah objek dari suatu kebijakan. Kebijakan dan program untuk memenuhi kebutuhan publik dapat dicapai secara efektif dan bertanggungjawab melalui upaya kolektif dan proses kolaboratif. Sesuai dengan prinsip new public service yaitu think strategically act democratically. Hal ini menegaskan bahwa keberhasilan penyelenggaraan pendidikan inklusif tidak hanya bergantung pada satu pihak saja.

Penyelenggaraan pendidikan inklusif telah melibatkan masyarakat dalam pelaksanaanya. Proses keterwakilan ini telah dipersiapakan dengan memasukan orang tua wali ke dalam komite sekolah. Memang tidak semua orang tua harus masuk ke komite sekolah, akan tetapi cukup dengan perwakilan beberapa orang tua baik orang tua dari anak normal maupun anak berkebutuhan khusus. Hal ini sangat berguna untuk melakukan musyawarah dalam mengambil kebijakan mengenai penyelenggaraan pendidikan inklusif. Tidak semua kebijakan diatur dan ditentukan oleh komite sekolah. Beberapa kebijakan mengenai penyelenggaran pendidikan inklusif harus ditentukan sendiri oleh sekolah dan diketahui oleh komite.

Keterwakilan juga ditunjukan dengan melibatkan orang tua siswa dalam penerimaan siswa baru. Hal ini dilakukan dengan melakukan wawancara secara langsung kepada para orang tua. Wawancara berguna untuk mengetahui tingkat kemampuan siswa dalam mengikuti belajar mengajar. Wawancara juga dilakukan untuk mengetahui kekurangan dan kebutuhan yang harus diberikan pihak sekolah kepada siswa berkebutuhan khusus. Setelah melakukan wawancara dan pihak sekolah mengetahui tingkat kemampuan siswa, sekolah dapat membuat kebijakan khusus untuk siswa yang berkebutuhan khusus.

\section{Kemampuan Pemerintah dalam Merumuskan dan Menyesuaikan Regulasi dalam Penyelenggaraan Pendidikan Inklusif \\ Dwiyanto \\ (2006:50) menjelaskan} responsivitas adalah kemampuan organisasi untuk mengenali kebutuhan masyarakat, menyusun agenda dan prioritas pelayanan, dan mengembangkan program-program pelayanan publik sesuai dengan kebutuhan dan aspirasi masyarakat[3]. Akses, pilihan, informasi, perbaikan dan keterwakilan merupakan bentuk kepekaan pemerintah terhadap masalah yang timbul di masyarakat. Setelah adanya kepekaan perlu disambung dengan kemampuan dalam menyelesaikan masalah yang ada. Sesuai dengan pengertian responsivitas menurut Tangkisilan (2005:177) yang menjelaskan bahwa responsivitas menunjuk pada keselarasan antara program dan 
kegiatan pelayanan dengan kebutuhan masyarakat[13]. Kemampuan ditunjukan dengan pembuatan regulasi untuk menyelesaikan masalah yang ada. Hal ini sesuai dengan prinsip new public service yaitu recognize that accountability is not simple. Bahwa abdi masyarakat seharusnya lebih peduli daripada mekanisme pasar. Selain itu, abdi masyarakat juga harus mematuhi peraturan perundang-undangan, nilai-nilai kemasyarakatan, norma politik, standar profesional dan kepentingan warga negara.

Regulasi diperlukan untuk mengatur penyelenggaraan pendidikan inklusif dengan semakin bertambahnya anak berkebutuhan khusus di Kota Surakarta yang masuk ke sekolah inklusi. Pada tahun 2009 tercatat hanya ada 39 anak berkebutuhan khusus yang sudah memanfaatkan sekolah inklusi. Jumlah tersebut terus bertambah sesuai keinginan anak berkebutuhan khusus yang ingin masuk ke sekolah inklusi, sehingga pada tahun 2013 tercatat ada 276 anak yang sudah memanfaatkan sekolah inklusi. Selain bertambahnya jumlah anak berkebutuhan khusus yang memanfaatkan sekolah inklusi, jumlah sekolah inklusi juga bertambah. Hal ini merupakan salah satu bentuk kepekaan pemerintah untuk memberikan pilihan kepada masyarakat. Sebelum resmi menjadi kota inklusi, Kota Surakarta hanya memiliki 13 sekolah inklusi. Pada tanggal 23 september 2013, Kota Surakarta resmi menjadi kota inklusi, kemudian meresmikan 13 sekolah inklusi yang sudah berjalan dan 15 sekolah inklusi yang baru. Total 28 sekolah inklusi yang berada di Kota Surakarta.

Semakin banyak masyarakat yang memanfaatkan pelayanan dan semakin banyak pilihan yang diberikan oleh pemerintah. Perlu dibarengi dengan pengaturan penyelenggaraan pelayanan yang berupa regulasi. Regulasi yang dibuat oleh pemerintah Kota Surakarta bertujuan mengatur penyelenggaraan pendidikan inklusif agar dapat berjalan sesuai dengan keinginan dan kebutuhan masyarakat Kota Surakarta. Kota Surakarta sudah memiliki regulasi mengenai penyelenggaraan pendidikan inklusif. Regulasi tersebut adalah Surat Keputusan Kepala Dinas Pendidikan, Pemuda dan Olahraga Kota Surakarta No 954/55/kep/sd-AUD/2013 tentang penetapan sekolah penyelenggara pendidikan inklusif Kota Surakarta. Keputusan tersebut menetapkan 28 sekolah penyelenggara inklusi. terdiri dari 15 SD, 7 SMP, 3 SMA dan 3 SMK, yang tersebar di 5 kecamatan di Kota Surakarta. Sesuai dengan tujuan dari pendidikan inklusif yang dijelaskan oleh Trimo (2012) yaitu: (1) memberikan kesempatan yang seluas-luasnya kepada semua peserta didik yang memiliki kelainan fisik, emosional, mental, dan sosial, atau memiliki potensi kecerdasan dan/atau bakat istimewa untuk memperoleh pendidikan yang bermutu dan berkesinambungan sesuai dengan kebutuhan dan kemampuannya, (2) mewujudkan penyelenggaraan pendidikan yang menghargai keanekaragaman, dan tidak diskriminatif bagi semua peserta didik berkebutuhan khusus, dan (3) memperluas pemerataan dan akses pendidikan bagi semua anak dalam rangka penuntasan wajib belajar pendidikan dasar 9 tahun di Indonesia[14].

Regulasi selanjutnya adalah Perda Kota Surakarta No 4 Th 2012 tentang Perlindungan Anak. Peraturan Daerah Kota Surakarta Nomor 4 Tahun 2012 tentang Perlindungan Anak menjelaskan bahwa hak anak adalah bagian dari hak asasi manusia yang wajib dijamin, dilindungi, dan dipenuhi oleh orang tua, keluarga, masyarakat, pemerintah daerah. Perlindungan ini termasuk perlindungan dalam bidang pendidikan yang ditujukan kepada anak berkebutuhan khusus. Perda tersebut juga mengatur pihak yang harus ikut serta dalam perlindungan anak. Antara lain, pemerintah, masyarakat dan orang tua. Kelemahan dari perda tersebut adalah belum mengatur secara khusus pelaksanaan pendidikan inklusif.

\section{KESIMPULAN}

Kepekaan pemerintah dalam penyelenggaraan pendidikan inklusif telah ditunjukan dengan pemberian akses yang lebih luas kepada anak berkebutuhan khusus dalam bidang pendidikan yaitu pendidikan inklusif. Pendidikan inklusif juga merupakan bukti bahwa pemerintah telah memberikan lebih banyak pilihan untuk masyarakat. Penyelenggaraan juga disertai memberikan informasi mengenai penyelenggaraan pendidikan inklusif. Adanya perbaikan yang dilakukan melalui evaluasi baik isidental maupun kondisional. Pemerintah juga memberikan tempat untuk masyakarat dalam hal ini orang tua siswa bekrebutuhan khusus dalam mengambil keputusan dalam proses belajar mengajar.

Kemampuan pemerintah Kota Surakarta ditunjukan dengan memiliki regulasi mengenai pendidikan inklusif berupa Surat Keputusan Kepala Dinas Pendidikan, Pemuda dan Olahraga Kota Surakarta No 954/55/kep/sd-AUD/2013 tentang penetapan sekolah penyelenggara pendidikan inklusi Kota Surakarta dan Perda Kota Surakarta No 4 Th 2012 tentang Perlindungan Anak. Akan tetapi regulasi ini masih bersifat makro dan belum mengkhususkan terhadap ketentuan penyelenggaraan pendidikan inklusif.

Kebaruan penelitian ini adalah temuan bahwa reponsivitas pemerintah sangat diperlukan dalam 
penyelenggaraan pendidikan inklusif. Responsivitas tersebut berupa kepekaan dan kemampuan pemerintah. Kepekaan ditunjukan dengan 5 aspek, yaitu akses, pilihan, informasi, keterwakilan dan perbaikan. sedangkan kemampuan ditunjukan dengan adanya regulasi yang dibuat oleh pemerintah. Kelebihan dari penelitian ini adalah memotret daya tanggap pemerintah mengenai kebutuhan masyarakat khususnya anak berkebutuhan khusus, mengenai keadilan dalam hal pendidikan yang layak. Masih terdapat kekurangan dari penelitian ini yaitu tidak dilakukannya penelitian mengenai implementasi dari regulasi yang telah dibuat pemerintah mengenai penyelenggaraan pendidikan inklusif.

\section{SARAN}

Akses harus dilengkapi dengan sarana dan prasana yang memudahkan anak berkebutuhan khusus masuk dalam sekolah inklusi. Sarana prasarana ini dapat berbentuk buku braile untuk anak tuna netra, alat bantu dengar untuk anak tuna rungu, atau jalan khusus untuk kursi roda bagi mereka yang menggunakan kursi roda. Pilihan yang diberikan harus memiliki kualitas yang baik, sehingga perlu mendatangkan guru pendidikan khusus dari SLB ke sekolah inklusi. Selain itu juga perlu adanya pelatihan-pelatihan untuk guru pendidikan khusus yang mengajar di sekolah inklusi. Informasi yang diberikan harus jelas, hal ini perlu dilakukan dengan memasang baliho atau papan pengumuman di masing-masing sekolah. Perbaikan yang dilakukan oleh pihak sekolah harus selalu diawasi oleh dinas terkait, agar tidak terjadi kesalahan dalam melakukan evaluasi. Keterwakilan perlu dilakukan dengan cara soasialisasi terhadap orang tua mengenai kebijakan penyelenggaraan pendidikan inklusif. Hal ini bisa dilakukan setiap akhir semester ketika pengambilan hasil belajar siswa.

Regulasi untuk mengenai penyelenggaraan pendidikan khusus harus segera dirancang dan disahkan oleh Pemerintah Kota Surakarta. Regulasi harus mencakup hal-hal seperti kurikulum untuk anak berkebutuhan khusus, hak dan kewajiban anak berekebutuhan khusus yang masuk dalam sekolah inklusi serta guru yang mengajar dalam kelas-kelas inklusi.

\section{UCAPAN TERIMA KASIH}

Terimakasih kepada Dinas Pendidikan Pemuda dan Olahraga Kota Surakarta, serta sekolah-sekolah penyelenggara pendidikan inklusif yang berada di Kota Surakarta.

\section{DAFTAR PUSTAKA}

[1]. Astuti, Made Sadhi. 2003. Hukum Pidana Anak dan Perlindungan Anak, Universitas Negeri Malang. Malang.

[2]. Denhart, Janer V, and Robert B. denhart. 2013. Pelayanan Publik Baru. Terjemah Oleh Saut Pasaribu. Cetakan Pertama. Kreasi Wacana. Bantul.

[3]. Dwiyanto, Agus, dkk. 2006. Reformasi Birokrasi Publik di Indonesia, Gadjah Mada University Press. Yogyakarta.

[4]. Hardiansyah. 2011. Kualitas Pelayanan Publik, Konsep, Dimensi, indikator dan Implementsinya, Gava Media. Yogyakarta.

[5]. Islamy, M.I. 2007. Manajemen Perubahan di Sektor Publik. FIA-UNIBRAW. Malang.

[6]. Mahmudi,. 2007. Manajemen Kinerja Sektor Publik, Sekolah Tinggi Ilmu Manajemen YKPN. Yogyakarta.

[7]. Maruti, Sri Kusrini. 2013. Responsivitas Pelayanan Kantor Pertanahan Kota Salatiga. Pascasarjana UNS. Surakarta.

[8]. Pasolong, Harbani. 2008. Teori Administrasi Publik, CV Alfabeta. Bandung.

[9]. Peraturan Daerah Kota Surakarta Nomor 4 Tahun 2012 tentang Perlindungan Anak.

[10]. Sjamsuddin, Sjamsiar. 2006. Dasar-Dasar dan Teori Administrasi Publik. Yayasan Pembangunan Nasional. Malang.

[11]. Straus, Anselm dan Robert Corbin. 2003. Dasar-Dasar Penelitian Kualitatif. Terjemah oleh Muhammad Shodiq dan Imam Muttaqien. Cetakan Pertama. Pustaka Pelajar. Yogyakarta.

[12]. Supriyono, Bambang. 2001. "Responsivitas dan Akuntabilitas Sektor Publik",: Jurnal Administrasi Negara Vol 1 No 2, 2 Maret 2001, FIA. Malang.

[13]. Tangkisilan, Hesel Nogi S. 2005. Manajemen Publik, PT. Grasindo. Jakarta.

[14]. Trimo, 2012. "Manajemen Sekolah Penyelenggara Pendidikan Inklusif: Kajian Aplikatif Pentingnya Menghargai Keberagaman Bagi Anak-Anak Berkebutuhan Khusus", : JMP, Volume 1 Nomor 2, Agustus 2012, Kendal. http://portalgaruda.org/article.

[15]. Undang-Undang Republik Indonesia Nomor 23 Tahun 2002 tentang Perlindungan Anak.

[16]. Widodo, Djoko. 2001. Akuntabilitas Dan Kontrol Birokrasi. Insan Cendikia. Surabaya. 